\title{
Differences in Duodenal Mast Cell and Eosinophil Counts Between Patients With Functional Dyspepsia and Healthy People
}

\author{
MohammadMahdi Hayatbakhsh Abbasi ${ }^{1}$, Elham jafari ${ }^{2, *}$, Mohammadjavad zahedi ${ }^{1}$, \\ Sodaif Darvish Moghaddam ${ }^{1}$, Aboozar taghizadeh ${ }^{3}$, Negin kharazmi ${ }^{3}$
}

1. Professor of Internal Medicine, Gastroenterology and Hepatology Research Center, Kerman University of Medical Sciences, Kerman, Iran.

2. Associate Professor, Pathology and stem cells Research Center, Kerman University of Medical Sciences, Kerman, Iran.

3. Researcher, Pathology and stem cells Research Center, Kerman University of Medical Sciences, Kerman, Iran

\footnotetext{
* Corresponding Author:

Elham Jafari, MD,AP.CP.

Pathology and stem cells research center, Kerman University of Medical Science, Kerman, Iran ORCID: 0000-0001-9240-9177

Telefax: + 983432223066 Email: ejfarda@yahoo.com

Received : 20 Apr. 2021 Accepted : 09 Sep. 2021
}

\section{ABSTRACT}

\section{BACKGROUND}

Functional dyspepsia is a common, troubling, and usually chronic disorder. Although the merit of using pathological assays has not been confirmed, medications affecting eosinophils may result in some improvements. Disseminated distribution of mast cells may also be an essential factor. Given the probable associations and lack of evidenced-based data, this study was conducted to comparatively investigate the number of eosinophils and mast cells in the duodenum in functional dyspepsia patients and healthy controls.

\section{METHODS}

In this case-control study, 150 consecutive subjects in Kerman, Iran, were enrolled in 2015 and 2016; the subjects consisted of 100 patients with functional dyspepsia and 50 asymptomatic healthy controls. Samples from the two groups were compared for the number of eosinophils, mast cells, and Helicobacter pylori presence by grasp biopsy.

\section{RESULTS}

The mean number of mast cells significantly differed between the groups $(\mathrm{P}=0.001)$, but the eosinophil count was similar $(p>0.05)$. Female gender, no opioid use, and H. pylori may increase mast cell count $(p<0.05)$.

\section{CONCLUSION}

Overall, the mast cell count was significantly different between people with functional dyspepsia and people without it, but the eosinophil count in the two groups was similar.

\section{KEYWORDS:}

Functional Dyspepsia, Inflammation, Duodenum

Please cite this paper as:

Hayatbakhsh Abbasi MM, Jafari E, zahedi MJ, Darvish Moghaddam S, Taghizadeh A, kharazmi N. Differences in duodenal mast cell count and eosinophil count between patients with functional dyspepsia and healthy people. Middle East J Dig Dis 2021;13: 333-338. doi: $10.34172 /$ mejdd.2021.243

\section{INTRODUCTION}

Functional dyspepsia is a common, troubling, and usually chronic disorder lasting for over three months. Functional dyspepsia is seen in 40 percent of adults, ${ }^{1-5}$ and it is usually diagnosed around six months after initiation. This disorder can result in an immense economic burden and a large number of 
referrals to primary or tertiary healthcare centers. ${ }^{6-9}$ Multiple mechanisms have been proposed: gastric emptying disorder, geographical variations, food hypersensitivity, dysmotility, and organ hyper-sensitization. ${ }^{10-12}$ Regarding mental consequences, ${ }^{13}$ recognition of contributing etiologies is essential and inflammatory processes with eosinophil and mast-cell infiltration have shown some roles ${ }^{14,15}$ Eosinophils are seen in the duodenum in 71 to 95 percent of subjects with functional dyspepsia. ${ }^{16,17} \mathrm{Al}-$ though there is no confirmation of using pathological assays, ${ }^{18}$ medications affecting the eosinophils may result in some improvements. ${ }^{19,20}$ Disseminated distribution of mast cells may also be an important factor. ${ }^{21}$ Recent studies have shown that mast cells and eosinophils are related to each other as eosinophils activate mast cells using mediators and growth factors. Also, the interaction of these two cell groups is involved in the development of visceral hypersensitivity and correlated with the symptoms of functional dyspepsia.$^{15,19-20}$

Due to the proposed associations and lack of evidenced-based data, this study was conducted to compare the number of eosinophils and mast cells in the duodenum in patients suffering from functional dyspepsia with healthy control subjects.

\section{MATERIALS AND METHODS}

In this case-control study, 150 consecutive subjects were enrolled in 2015 and 2016 in Kerman, Iran; the population included 100 patients with functional dyspepsia and 50 asymptomatic healthy control subjects. Inclusion criteria were age over 18 , dyspepsia for more than three months during the previous six months, and normal endoscopic features. Also, the subjects with celiac disease, cancer, or peptic ulcers and those with a history of NSAID use or positive anti-tTG were excluded. Informed consent was acquired from participants. This study was approved by the Ethics Committee of Kerman University of Medical Sciences, Kerman, Iran [IR.KMU.RITC.1394.555].

Data including age, gender, literacy, financial status, residence region, previous medical conditions, family history, smoking, opioid use, symptom duration, and clinical symptoms were gathered using checklists. Grasp biopsy was attained under sedation from the first and second parts of the duodenum and fixed in formalin 10\%; hematoxylin and eosin staining were done along with immunohistochemical staining for CD117. The samples in the two groups were compared considering the number of eosinophils, mast cells, and Helicobacter pylori presence through a urease breath test and gastric antrum biopsy. Eosinophil and mast cell count was numbered in minimally five random high power fields without overlapping in portions where the Brunner's glands were not dense. Eosinophils were counted in slides stained with $\mathrm{H} \& \mathrm{E}$, which appeared bright pink, and the mast cells were assessed with the immunocytochemistry staining method using rabbit anti-human polyclonal antibody CD117 (ckit; Dako, UK) and a microscope (CX-33; Olympus, Tokyo, Japan) at $\times 400$ magnification. (Figure 1). All slides were assessed by two blinded pathologists. Previous studies for duodenal eosinophil counts have shown less than 10 per high-power field (10/1 HPF) and 19.5 HPFs as normal for children and adults, respectively. ${ }^{15}$ Mast cells in the normal duodenum have been previously counted with an average of 13 cells per high-power field and can vary depending upon the immunologic status of the subjects. ${ }^{22}$

Data analysis was performed among 150 subjects using SPSS (version 21.0) software [Statistical Procedures for Social Sciences; Chicago, Illinois, USA]. Chi-square and independent-sample t-tests were used and were considered statistically significant at $P$ values less than 0.05 .

\section{RESULTS}

In this study $55(55 \%)$ and $29(58 \%)$ subjects were male in case and control groups, respectively $(P>0.05)$. In $31(31 \%)$ and $17(34 \%)$ cases, opioid use history was positive in the case and control group, respectively ( $p>$ 0.05). In 17 (17\%) and 10 (20\%) cases, smoking history was positive in the case and control groups, respectively $(p>0.05)$. The urease test for Helicobacter pylori was positive in $31(31 \%)$ and $25(50 \%)$ subjects in the case and control groups, respectively $(p=0.001)$. Also, the Helicobacter pylori colonization was confirmed in 33 $(33 \%)$ and $27(54 \%)$ of subjects in the case and control groups, respectively $(p=0.001)$, in the gastric mucosal biopsy. However, as expected, urease test during endoscopy and the presence of Helicobacter pylori in the gastric mucosal biopsy in the case group was significantly 

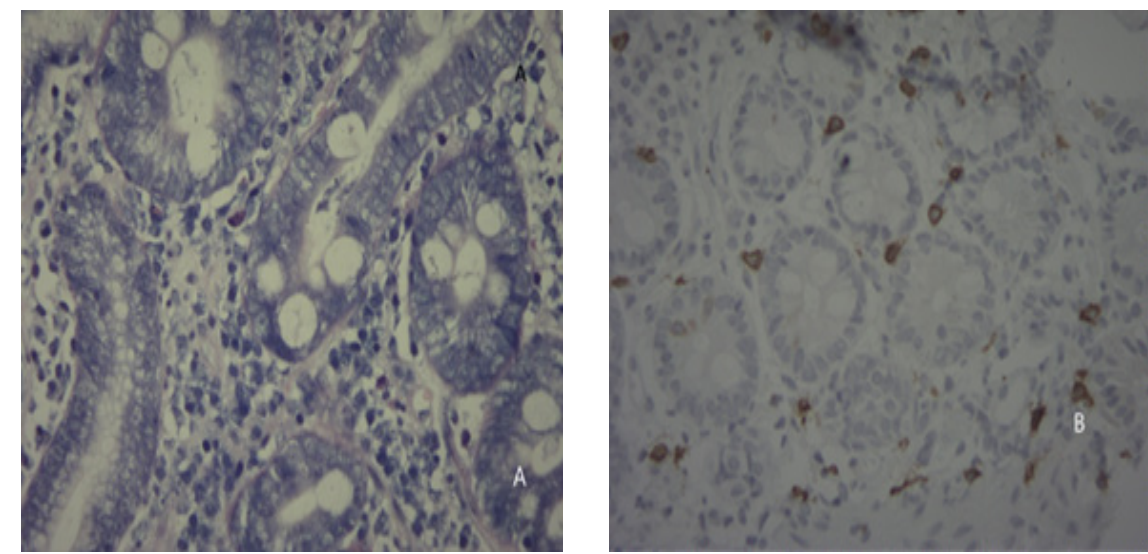

Fig.1 : A: microscopic view of the first portion of the duodenum mucosal layer with $\mathrm{H} \& \mathrm{E}$ staining $(\times 400)$

B: microscopic view of the first portion of the duodenum mucosal layer with CD117 IHC staining $(\times 400)$

higher than in healthy controls.

However, the mean number of mast cells in D1 was significantly $(p=0.010)$ higher in female versus male subjects in the case group ( $33.5 \pm 8.5$ versus $27.9 \pm 6.2)$; the mast cell counts in D2 and the eosinophil count in D1 and D2 were alike across the genders $(p>0.05)$.

Concerning opioid use, the eosinophil count in D2 was the only changed $(p=0.004)$ item, and concerning smoking, there was no significant difference $(p>0.05)$. The data of the present study also showed that age and other factors, including clinical symptoms, did not have a significant correlation with the number of eosinophil and mast cells in the first and second parts of the duodenum (Table 1).

In those with Helicobacter pylori infection, there was only a significant difference for eosinophil count in D2 in the case group (Table 2).

Mean mast cells and eosinophils in D1 and D2 differed in none of the groups $(p>0.05)$, but case and control groups had significant differences with each other $(p=$ $0.001)$ in mast cell count, but not in eosinophil count ( $p>$ $0.05)$. The mean numbers of mast cells in D1 and D2 were significantly higher in the case group, but the eosinophil count was similar in different groups (Table 3 ).

\section{DISCUSSION}

In this study, the number of eosinophils and mast cells in the duodenum in patients with functional dyspepsia versus healthy control subjects were compared. It was found that the mean number of mast cells was significantly different across the groups, but the eosinophil counts were alike. However, the mean number of mast cells in D1 was significantly higher in female subjects compared to male subjects in the case group; the mast cell counts in D2 and eosinophil count in D1 and D2 were alike across the genders. Age, smoking, and opioid use had no significant association pattern except for the eosinophil count in D2 in opioid users. Female subjects had a higher mast cell count in D1 due to hormonal or nutritional differences compared with male subjects. Higher eosinophil count in D2 was related to positive Helicobacter pylori status. Similar to our study, the study by Mirbagheri et al. ${ }^{23}$ reported a significant association between duodenal inflammation and H. pylori infection in patients with functional dyspepsia.

In the study of Mirbagheri et al. in Tehran, the trunk, stomach, and duodenum of 217 adults with functional dyspepsia and normal endoscopy findings were biopsied. The biopsies were examined for the presence of $H$. pylori. The presence of $H$. pylori was detected in $67 \%$ (n = 146) of cases. In 120 patients with $H$. pylori, microscopic duodenitis was also observed, indicating a strong association between $H$. pylori infection and microscopic duodenitis. However, H. pylori was present in 33\% of dyspepsia cases in our study. ${ }^{23}$

Walker et al. ${ }^{24}$ reported no significant difference between eosinophil and mast cell counts between those with dyspepsia and control subjects. This was also reported by Vanheel et al. ${ }^{25}$ These findings are in line with the eosinophil count results in our study, but not with those of the mast cell count. Talley et al. ${ }^{26}$ reported differences in eosinophil counts in the first and second parts of the 
Table 2: Number of mast cells and eosinophils across the groups

\begin{tabular}{lccc}
\hline Item & $\begin{array}{c}\text { Positive for } \\
\boldsymbol{H} \text {. pylori }\end{array}$ & $\begin{array}{c}\text { Negative for } \\
\boldsymbol{H} \text {.pylori }\end{array}$ & $\begin{array}{c}\boldsymbol{p} \text { - } \\
\text { value }\end{array}$ \\
\hline & & & \\
Mean mast cell in D1 & $30.9 \pm 5.6$ & $29.6 \pm 8.4$ & 0.586 \\
Mean eosinophil in D1 & $32.6 \pm 7.3$ & $28.4 \pm 9.1$ & 0.610 \\
Mean mast cell in D2 & $6.4 \pm 4.5$ & $6.0 \pm 4.5$ & 0.672 \\
Mean eosinophil in D2 & $7.1 \pm 3.2$ & $6.5 \pm 4.1$ & 0.033 \\
\hline
\end{tabular}

Table 3: Number of mast cells and eosinophils across the groups

\begin{tabular}{lccc}
\hline Item & Case group & $\begin{array}{c}\text { Control } \\
\text { group }\end{array}$ & $\boldsymbol{p}$-Value \\
\hline Mean mast cell in D1 & $30.06 \pm 1.06$ & $17.2 \pm 0.90$ & 0.001 \\
Mean eosinophil in D1 & $6.13 \pm 0.44$ & $6.07 \pm 0.54$ & 0.938 \\
Mean mast cell in D2 & $29.73 \pm 1.22$ & $16.72 \pm 0.92$ & 0.001 \\
Mean eosinophil in D2 & $6.70 \pm 0.38$ & $5.67 \pm 0.46$ & 0.105 \\
\hline
\end{tabular}

duodenum. This was also reported in studies by Walker et al. ${ }^{27,28}$ A significant difference in eosinophil count has also been reported in other studies. ${ }^{12,29-30}$

In the study of Talley et al. on 51 adult patients with functional dyspepsia and 48 controls, the mean count of eosinophils in the first and second part of the duodenum was significantly different between the case and control groups,${ }^{26}$ which is not in agreement with our study.

The results of one study in Yazd, central Iran (2013), in which the stomach and duodenum of 25 functional dyspepsia patients and 27 controls were biopsied, were similar to our study concerning eosinophil number. In that study, the density of eosinophils and mast cells in the duodenum, determined by their median number, was not significantly different between the two groups. However, in our study, the mean number of mast cells, but not that of eosinophils, in the two groups was significantly different. $^{14}$

Like most studies, in our study, a significant difference was observed in mast cell numbers in the first and second parts of the duodenum between the case and control groups. Walker et al. (2009) conducted a study on 51 patients with functional dyspepsia, 41 patients with IBS, and 48 individuals as controls ${ }^{27}$ and showed the mean mast cell count in the second part of the duodenum was significantly different between the case and control groups, which is in line with our findings. ${ }^{27}$ In another study by Walker et al. (2011), mast cell number
Table 1: Role of background factors

\begin{tabular}{|c|c|c|c|}
\hline Variables & Male & Female & $P$-value \\
\hline & & $33.5 \pm 8.5$ & \\
\hline D1 mast cell count & $27.9 \pm 6.2$ & $31.8 \pm$ & 0.01 \\
\hline D2 mast cell count & $28.5 \pm 7.1$ & 10.8 & 0.195 \\
\hline D1 eosinophil count & $6.1 \pm 4.8$ & $6.1 \pm 3.9$ & 0.982 \\
\hline \multirow[t]{2}{*}{ D2 eosinophil count } & $6.5 \pm 3.9$ & $\begin{array}{c}7.01 \pm \\
3.72\end{array}$ & 0.467 \\
\hline & Addict & $\begin{array}{l}\text { Non- } \\
\text { addict }\end{array}$ & \\
\hline D1 mast cell count & $28.2 \pm 5.8$ & $30.7 \pm 8.1$ & 0.302 \\
\hline D2 mast cell count & $30.1 \pm 8.5$ & $29.6 \pm 8.8$ & 0.864 \\
\hline D1 eosinophil count & $4.9 \pm 3.4$ & $6.6 \pm 4.8$ & 0.074 \\
\hline \multirow[t]{2}{*}{ D2 eosinophil count } & $5.2 \pm 2.9$ & $7.3 \pm 4.01$ & 0.004 \\
\hline & Smoker & $\begin{array}{c}\text { Non- } \\
\text { smoker }\end{array}$ & \\
\hline D1 mast cell count & $26.2 \pm 5.8$ & $31.1 \pm 7.7$ & 0.056 \\
\hline D2 mast cell count & $28.3 \pm 8.3$ & $30.1 \pm 8.8$ & 0.567 \\
\hline D1 eosinophil count & $5.4 \pm 0.8$ & $4.6 \pm 0.5$ & 0.519 \\
\hline \multirow[t]{2}{*}{ D1 eosinophil count } & $5.4 \pm 3.1$ & $6.9 \pm 3.9$ & 0.085 \\
\hline & \multicolumn{2}{|c|}{$\begin{array}{l}\text { Regression Coefficient } \\
\text { (Correlation with age of } \\
\text { case group) }\end{array}$} & $p$-value \\
\hline D1 mast cell count & \multicolumn{2}{|c|}{0.067} & 0.640 \\
\hline D2 mast cell count & \multicolumn{2}{|c|}{-0.002} & 0.990 \\
\hline D1 osinophil count & \multicolumn{2}{|c|}{0.096} & 0.344 \\
\hline D2 osinophil count & \multicolumn{2}{|c|}{0.092} & 0.356 \\
\hline
\end{tabular}

increased in functional dyspepsia. ${ }^{28}$

The study of Wang et al. showed that the mean mast cell number in the first and second parts of the duodenum was significantly different between the case and control groups but did not observe significant differences in eosinophil counts in D1 between these groups, ${ }^{30}$ a result also achieved by our study.

Concerning the role of smoking, we did not find significant differences in our study; however, such differences were reported by Walker et al. ${ }^{24}$ These incongruities in results demonstrate the presence of a multidimensional network of etiologies, which should be comprehensively assessed in further studies if we are to attain more definite results.

Ethnic, geographical, and cultural diversity may be essential factors leading to differences between the results of various studies. This matter may also result in some diversity across the same country.$^{14}$

The current study had certain limitations. First, the case-control, observational design of this study predisposes the selection process to bias and, therefore, challenges the reliability of the main findings; secondly, all participants belong to the same community, which may 
challenge the generalizability of the results to other communities; thirdly, our sample size was comparably small, which may potentially influence the validity of our research.

\section{CONCLUSION}

It may be concluded that mast cells were significantly different between those with functional dyspepsia and control subjects, but the eosinophil count was almost the same. Also, female gender, no opioid use, and H. Pylori may increase mast cell count. However, further studies with larger sample sizes, the equal sample size in the two groups, and the consideration of confounding factors such as therapeutic regimens should be conducted to reach more definite results.

\section{ACKNOWLEDGMENTS}

This work was financially supported by the Digestive Research Center, Kerman University of Medical Sciences, Kerman, Iran (Grant no.: 95/482).

\section{ETHICAL APPROVAL}

There is nothing to be declared.

\section{CONFLICT OF INTEREST}

The authors declare no conflict of interest related to this work

\section{REFERENCES}

1. Talley NJ, Zinsmeister AR, Schleck CD, Melton LJ. Dyspepsia and dyspepsia subgroups: a populationbased study. Gastroenterology 1992;102:1259-68.doi: 10.1016/0016-5085(92)90764-P.

2. Marin F, Cucala M, Azpiroz F, Malagelada JR. The origin of symptoms on the brain-gut axis in functional dyspepsia. Gastroenterology 1991;101:999-1006.doi: 10.1016/0016-5085(91)90726-2.

3. Talley NJ, Walker MM, Holtmann G. Functional dyspepsia. Curr Opin Gastroenterol 2016;32:467-73. doi: 10.1097/MOG.0000000000000306.

4. Jones R, Lydeard S, Hobbs F, Kenkre J, Williams E, Jones S, et al. Dyspepsia in England and Scotland. Gut 1990;31:401-5.doi: 10.1136/gut.31.4.401

5. Tack J, Bisschops R, Sarnelli G. Pathophysiology and treatment of functional dyspepsia.Gastroenterology 2004;127:1239-55.doi: 10.1053/j.gastro.2004.05.030

6. Henningsen P, Zimmermann T, Sattel H. Medically unexplained physical symptoms, anxiety, and depression: a meta-analytic review. Psychosom Med 2003;65:528-33. doi: 10.1097/01.psy.0000075977.90337.e7.

7. Feldman M, Friedman LS, Brandt LJ. Sleisenger and Fordtran's gastrointestinal and liver disease: pathophysiology, diagnosis, management, expert consult premium edition enhanced online features: Elsevier Health Sci 2010.

8. Knill-Jones R. Geographical differences in the prevalence of dyspepsia. Scand J Gastroenterol Suppl 1991;182:1724. doi: 10.3109/00365529109109532.

9. Drossman DA, Li Z, Andruzzi E, Temple RD, Talley NJ, Grant Thompson W, et al. US householder survey of functional gastrointestinal disorders. Dig Dis Sci 1993; 38:1569-80. doi: 10.1007/BF01303162.

10. Tack J, Lee K. Pathophysiology and treatment of functional dyspepsia. J Clin Gastroenterol 2005;39:S211-6. doi: 10.1097/01.meg.0000156109.97999.d1

11. Tack J, Talley NJ, Camilleri M, Holtmann G, Hu P, Malagelada JR, et al. Functional gastroduodenal disorders. Gastroenterology 2006;130:1466-79.doi:10.1053/j. gastro . 2005.11.059.

12. Lee KJ, Tack J. Duodenal implications in the pathophysiology of functional dyspepsia. $J$ Neurogastroenterol Motil 2010;16:251-7.doi: 10 .5056 /jnm. 2010 .16.3.251

13. Rippel SW, Acra S, Correa H, Vaezi M, Di Lorenzo C, Walker LS. Pediatric patients with dyspepsia have chronic symptoms, anxiety, and lower quality of life as adolescents and adults. Gastroenterology 2012;142:754-61. doi: 10.1053 /j.gastro .2011.12.043.

14. Binesh F, Akhondei M, Pourmirafzali H, Rajabzadeh Y. Determination of relative frequency of eosinophils and mast cells in gastric and duodenal mucosal biopsies in adults with non-ulcer dyspepsia. J Coll Physicians Surg Pak 2013;23:326-9.

15. Wang X, Li X, Ge W, Huang J, Li G, Cong Y, et al. Quantitative evaluation of duodenal eosinophils and mast cells in adult patients with functional dyspepsia. Ann Diagn Pathol 2015;19:50-6. doi: 10.1016/j.anndiagpath.2015.02.001.

16. Kindt S, Van Oudenhove L, Broekaert D, Karan A, Ceuppens $\mathrm{J}$, Bossuyt $\mathrm{X}$, et al. Immune dysfunction in patients with functional gastrointestinal disorders. Neurogastroenterol Motil 2009 ;21:389-98. doi: 10.1111/j.1365-2982 .2008 . $01220 . \mathrm{x}$

17. Friesen CA, Andre L, Garola R, Hodge C, Roberts C. Activated duodenal mucosal eosinophils in children with dyspepsia: a pilot transmission electron microscopic study. J Pediatr Gastroenterol Nutr 2002;35:329-33. doi:10.1097/00005176-2002 09000 -00017.

18. Friesen CA, Sandridge L, Andre L, Roberts CC, Abdel-Rahman SM. Mucosal eosinophilia and response to $\mathrm{H} 1 / \mathrm{H} 2$ antagonist and cromolyn therapy in pediatric dyspepsia. Clin Pediatr (Phila) 2006;45:143-7.doi: 0.1177/000992280604500205.

19. Walker MM, Salehian SS, Murray C, Rajendran A, Hoare J, Negus R, et al. Implications of eosinophilia in the normal 
duodenal biopsy-an association with allergy and functional dyspepsia. Aliment Pharmacol Ther 2010;31:122936. doi: $10.1111 /$ j.1365-2036.2010.04282.x.

20. Friesen CA, Kearns GL, Andre L, Neustrom M, Roberts CC, Abdel-Rahman SM. Clinical efficacy and pharmacokinetics of montelukast in dyspeptic children with duodenal eosinophilia. BMC Gastroenterol 2004;38:343-51. doi:10.1186/1471- 230X -9-32.

21. OsiyaSh M, Ghilian R, Kermanian A. Determination of Relative Frequency of Mast Cells and Eosinophils in Gastric Mucosa Biopsies in Children with Recurrent Abdominal Pain and Normal Endoscopy. Iran J Pediatr Hematol Oncol 2012;2: 22-9.

22. Ramsay DB, Stephen S, Borum M, Voltaggio L, and Doman DB. Mast Cells in Gastrointestinal Disease. Gastroenterol Hepatol (N Y) 2010; 6:772-7.

23. Mirbagheri A, Khajavirad N, Rakhshani N, Ostovaneh M, Eshaghhosseni M, Hoseini V. Impact of helicobacter pylori infection and microscopic duodenal histopathologic changes on clinical symptoms of patients whit functional dyspepsia. Dig Dis Sci 2012; 57:967-72. doi : 10.1007/ s10620-011-1960-z.

24. Walker MM, Aggarwal KR, Shim LS, Bassan M, Kalantar JS, Weltman MD, et al. Duodenal eosinophilia and early satiety in functional dyspepsia: confirmation of a positive association in an Australian cohort .J Gastroenterol Hepatol 2014 ;29:474-9. doi: 10.1111/jgh.12419.

25. Vanheel H, Vicario M, Vanuytsel T, Van Oudenhove L, Martinez C, Keita $\AA$ V, et al. Impaired duodenal mucosal integrity and low-grade inflammation in functional dyspepsia. Gut 2014 ;63:262-71. doi: 10.1136/ gutjnl-2012-303857.

26. Talley NJ, Walker MM, Aro P, Ronkainen J, Storskrubb T, Hindley LA, et al. Non-ulcer dyspepsia and duodenal eosinophilia: an adult endoscopic population-based casecontrol study. Clin Gastroenterol Hepatol 2007;5:117583.doi: 10.1016/j.cgh.2007.05.015.

27. Walker M, Talley N, Prabhakar M, Pennaneac'h C, Aro P, Ronkainen J, et al. Duodenal mastocytosis, eosinophilia and intraepithelial lymphocytosis as possible disease markers in the irritable bowel syndrome and functional dyspepsia. Aliment Pharmacol Ther 2009;29:765-73. doi:10.1111/j.13652036.2009.03937.x.10.1111/hel.12180

28. Walker MM, Warwick A, Ung C, Talley NJ. The role of eosinophils and mast cells in intestinal functional disease. Curr Gastroenterol Rep 2011;13:323-30. doi: 10.1007/ s11894-011-0197-5.

29. Walker MM, Salehian SS, Murray C, Rajendran A, Hoare J, Negus R, et al. Implications of eosinophilia in the normal duodenal biopsy-an association with allergy and functional dyspepsia. Aliment Pharmacol Ther 2010;31:122936. doi:10.1111/j.1365-2036.2010.04282.x

30. Wang X, Li X, Ge W, Huang J, Li G, Cong Y. Quantitative evaluation of duodenal eosinophils and mast cells in adult patients with functional dyspepsia. Ann Diagn Pathol 2015;19:50-6. doi: 10.1016/j.anndiagpath.2015.02.001. 